The University of Maine

DigitalCommons@UMaine

Publications

Senator George J. Mitchell Center for Sustainability

Solutions

9-1-2017

\title{
Fishing for Leadership: The Role Diversification Plays in Facilitating Change Agents
}

Joshua Stoll

University of Maine, joshua.stoll@maine.edu

Follow this and additional works at: https://digitalcommons.library.umaine.edu/ mitchellcenter_pubs

Part of the Environmental Studies Commons

\section{Repository Citation}

Stoll, Joshua, "Fishing for Leadership: The Role Diversification Plays in Facilitating Change Agents" (2017). Publications. 112. https://digitalcommons.library.umaine.edu/mitchellcenter_pubs/112

This Article is brought to you for free and open access by DigitalCommons@UMaine. It has been accepted for inclusion in Publications by an authorized administrator of DigitalCommons@UMaine. For more information, please contact um.library.technical.services@maine.edu. 
Fishing for Leadership: The Role Diversification Plays in Facilitating Change Agents

Joshua S. Stoll

210B Libby Hall, School of Marine Sciences, University of Maine, Orono, ME, 04469, USA

E-mail address: joshua.stoll@maine.edu. 


\section{ABSTRACT}

Leadership is often viewed as being critical to successful natural resource management. This research focuses on a set of leaders identified through a social network analysis of fishers in a rural coastal region. Leaders' connections to different fisheries are evaluated, and these actors are found to be significantly more diversified than other fishers in the area. Drawing on theory related to institutional entrepreneurship and a series of in-depth interviews with these actors, this paper puts forward several hypotheses to explain how diverse social-ecological connections facilitate leadership. Three mechanisms are identified. Being diversified facilitates:

(1) production of alternative visions; (2) framing of tractable strategies to sustain local marine resource; and (3) participation in the management process. While more research is needed to understand the relationship between diversification and leadership, these exploratory results suggest that leadership is, in part, a manifestation of ecological circumstance, supporting recent assertions that scholarship on leadership in natural resource management settings could benefit from being more attentive to the processes that shape leadership rather than fixating on individuals and their personal attributes. Given that fisheries policies increasingly constrain diversification, policymakers and managers should consider how specialization of fishers might change the form and function of leaders in the future.

Keywords

Leadership, Institutional entrepreneurship, Fisheries, Diversification, Maine 


\section{Introduction}

Leadership has been identified as an important component of successful natural resource management (Acheson, 2003; Bodin and Crona, 2008; Gilmour et al., 2013; Gutiérrez et al., 2011; Pinkerton, 1989; Sutton and Rudd, 2016). Leaders act to forward visions, facilitate collaboration, ameliorate conflict, and leverage resources, occupying both formal and informal positions of authority and power (Battilana et al., 2009). This research focuses on a set of leaders identified through a social network analysis of fishers in a rural coastal region. In this paper, leaders' connections to different fisheries are evaluated, showing that these actors are significantly more diversified than other fishers in the area. This finding raises the basic question: what is the relationship between leadership and actors' ties to the natural environment? Drawing on the theory of institutional entrepreneurship and a series of indepth interviews with these leaders, I investigate this question and outline several potential mechanisms that help to explain the relationship. By bringing explicit attention to the interplay between social-ecological connections and leadership, this research provides empirical evidence to suggest that fisher's diverse connections to fisheries are not decoupled from, but rather integral to the facilitation and maintenance of leadership in coastal communities. This finding lends support to the assertion that scholarship on leadership in natural resource management settings could benefit from being more attentive to the processes that shape and sustain leadership rather than continuing to fixate on individuals and their attributes (Evans et al., 2015; Sutton and Rudd, 2014; Westley et al., 2013). 
In this paper leaders are defined as actors who purposefully forward solutions that are intended to improve the social-ecological conditions of their communities. Although leadership can take multiple forms and serve diverse purposes, this definition is consistent with common conceptualizations of leadership in natural resource management contexts that focus on socialecological sustainability and transformation (Evans et al., 2015; Sutton and Rudd, 2014; Westley et al., 2013) (although see Khan et al., 2007; Crona and Bodin, 2010; and Steenbergen, 2016 for cases where leaders act to undermine systems). Those who occupy this role as "change agent" are often referred to as institutional entrepreneurs (IEs). Maguire et al. (2004) define IEs as “actors who have an interest in particular institutional arrangements and who leverage resources to create new institutions or transform existing ones." IEs are theorized to facilitate transformation by: (1) articulating alternative visions; (2) framing these visions in ways that resonate with others; and (3) guiding the implementation of these new visions through calculated engagement with other actors. Importantly, these strategies are relational, which means that institutional entrepreneurship is not an individualistic endeavor, but rather one that is determined in part by connections to other actors (Garud et al., 2007; Lawrence, 2004; Lounsbury and Crumley, 2007; Welter and Smallbone, 2011).

\subsection{Alternative visions, framing, and implementation}

Being able to imagine different outcomes is a necessary prerequisite to being able to forward alternative visions (Emirbayer and Mische, 1998). Yet this represents a significant challenge for IEs who are embedded in the systems that they are trying to change and whose cognitive framing 
is inevitably influenced by their surroundings (Garud et al., 2007; Hannan and Freeman, 1984; Lawrence, 2004; Levy and Scully, 2007; Pretty, 2003; Schusler et al., 2003; Seo and Creed, 2002). This challenge can be explained by the tendency for close associates that regularly interact to have similar perspectives because they share information, while those that interact less frequently tend to have more divergent views (McPherson et al., 2001). IEs are often able to side step this cognitive trap (at least in part) by engaging with actors outside their immediate communities and occupying bridging positions in social networks (Biggs et al., 2010; Maguire et al., 2004; Olsson et al., 2006, 2013; Rosen and Olsson, 2013). Granovetter (1973) asserts that such "weak ties" facilitate learning by creating critical pathways through which new knowledge can be acquired and subsequently repurposed.

IEs must also be able to persuade others that their visions are credible and should be supported (Biggs et al., 2010; Zilber, 2007). Battilana et al. (2009) convincingly argue that this is fundamentally a matter of problem framing. Specifically, they assert that IEs are effective at compelling actors to support alternative visions by way of diagnostic, prognostic, and motivational framing. Diagnostic framing illustrates the problem with the existing system; prognostic framing shows how the alternative vision addresses the issue; and motivational framing lays out a reason for actors to support the new vision. Just as social network position is key to being able to develop alternative visions, framing - which Olsson et al. (2006) refer to as "sense-making" - is also facilitated by the position that actors occupy in their social networks. IEs frequently occupy central nodes in their networks (Powell and DiMaggio, 2012). Such centrality means that IEs have a high "domain of influence" because the flow of goods and services (as well as knowledge and resources) often pass through them (Wasserman and Faust, 
1994). This role as arbiter gives IEs a rich understanding of the actors in their networks, whereby making it possible to effectively frame their visions in ways that are coherent and tractable to other actors in the system (Powell and DiMaggio, 2012).

In addition to these two strategies, IEs are also nimble and engage in different parts of the transformation process (Westley et al., 2011). Greenwood et al. (2002) identify six stages through which institutional entrepreneurship transpires: (1) precipitating jolts; (2) deinstitutionalization; (3) pre-institutionalization; (4) theorization; (5) diffusion; and (6) reinstitutionalization. In the initial phase, the system experiences some type of social or ecological impact that destabilizes the system. These events create space for IEs to introduce new visions (Biggs et al., 2010; Greenwood et al., 2002; McCarthy et al., 2014; Olsson et al., 2004). During phases 2 to 4, IEs work to disassemble existing norms and institutions by way of diagnostic, prognostic, and motivational framing (Biggs et al., 2010; Olsson et al., 2004). In the final phases, IEs actively work to transform the existing system by mobilizing resources and strategically engaging with different actors in the network at key moments in time (Biggs et al., 2010; Levy and Scully, 2007; Olsson et al., 2006; Perkmann and Spicer, 2007). This is not a unilateral process, but rather one that invariably requires give-and-take between actors.

\subsection{Broadening the theorization of leadership}

The central theme that weaves these three strategies (alternative visioning, framing, and implementation) together is the critical importance of IEs' relationships to the actors within their 
social networks. Acknowledging this theme helps to deemphasize both the heroic and individualistic nature of leadership, replacing it with a more context-based perspective (Lawrence, 2004; Levy and Scully, 2007; Lounsbury and Crumley, 2007). However, the emphasis that has been placed on broadening the theorization of institutional entrepreneurship to account for the contextual embeddedness of IEs has in itself been rather narrow - focusing primarily on actors' positions in their social network (McLaughlin and Dietz, 2008). This narrow focus is potentially problematic because actors' relationships to the natural environment (i.e., their social-ecological relationships) are also known to have a bearing on their knowledge, actions, and agency (Crona and Bodin, 2010; Hirsch Hadorn et al., 2006). For example, research on a coastal fishing community in East Africa found that opinion leaders' unwillingness to acknowledge fisheries declines and institutional changes in the governance structure was a function of their relationship to the marine environment (Crona and Bodin, 2010, 2006). This interplay between knowledge and the environment is also evident at the community-level, where recent scholarship on social-ecological networks has found that the success of natural resource management can be predicted based on the social and ecological linkages that exist in a system (Bodin et al., 2014; Bodin and Tengo, 2012). It is therefore reasonable to assume that without understanding leaders' ties to the natural environment, we cannot expect to fully understand their motivations, rationale, and strategies used to mobilize change. This invariably requires research on leadership that focuses more explicitly on the "contextual differences" that shape change (Sutton and Rudd, 2014).

Towards this objective, this research specifically focuses on the interplay between leaders and the natural environment in a coastal region of Maine, United States, exploring how fishers' 
particular connections to fisheries facilitate leadership. I begin by describing the socialecological context within which my research is situated. Next, I explain how leaders and their ties to different fisheries were identified and analyzed. Following this description, I present data showing that there is a significant difference between the diversification of leaders and other fishers in the region and across the state. I then draw on data from in-depth interviews with a subset of the identified leaders to put forward three potential mechanisms that help to explain the link between diversification and leadership within the context of the aforementioned theorization of institutional entrepreneurship. I conclude by discussing the relevance of these findings to those engaged in fisheries management and consider how trends in contemporary fisheries policy may alter leadership through time.

\section{Methods}

\subsection{Eastern Maine context}

Eastern Maine, known as "Downeast" on account of its geographic position relative to Boston, Massachusetts (i.e., downwind), stretches from the mouth of the Penobscot River eastward to Passamaquoddy Bay and includes the inshore waters of the Eastern Maine Coastal Current, which brings cold water along the western flank of the Scotian Shelf (Fig. 1). This rural stretch of Maine's coastline includes Hancock and Washington counties as well as a few of the easternmost islands in Knox County. In many respects, Downeast is relatively dislocated from the rest of the state and the Gulf of Maine because of its geographic isolation and unique geomorphology 
(NOAA, 2016). People in the region even have their own brogue, which was historically considered a "low-status" dialect of English (Goodman and Goodman, 1978).

Within the region, there are 9 coastal communities that have medium or high engagement in commercial fisheries (NOAA, 2016). These communities have a long tradition of commercial fishing and, to this day, continue to derive income from a range of marine resources, including urchins, scallops, shrimp, alewives, elvers, bluefin tuna, clams, marine worms, and lobster. Among these fisheries, lobster is of particular importance, accounting for more than $80 \%$ of the total value of fisheries in the region. Cook Aquaculture, Inc. also employs a significant number of people in eastern Maine. According to its website, the company produces more than 100,000 metric tons of Atlantic salmon in Canada and the US. Much of this product is raised in net pens in the coastal waters off Washington County. Those who do not fish (or do not fish year round) are often supported by other natural resource sectors in the region, including cutting timber, plowing snow, tipping trees for wreaths, or raking low-bush blueberries.

Like in many rural places, communities in Downeast face a range of chronic issues, including poverty ( $18.5 \%$ of households are below the poverty line), poor education (fewer than $20 \%$ hold a bachelors degree or higher), and drug abuse (U.S. Census Bureau, 2012). The geographic remoteness of the area also poses a problem for those who fish commercially because it is logistically difficult to participate in the policy and management process (Brzeinski et al., 2010). Parts of Downeast are two hundred miles from the state capital where many of the most important state fisheries management meetings are held, making the round-trip commute more 
than $6 \mathrm{~h}$ (in good weather). ${ }^{1}$ This travel time is often too costly for fishers from both a time and resources perspective. The same (in reverse) is also often true for policymakers and managers, who seldom make the trek to the region. This geographic isolation means that the only direct contact that many fishers have with formal fisheries management officials is with the local marine patrol officers and shellfish wardens.

To a certain extent, this disconnect has left the fishing industry to its own devices. Rule breaking is part of this reality. People openly talk about the extra lobster traps that are being fished, the illegal halibut fishing, clamming in closed areas, and those who exceed harvest limits in the scallop fishery. Yet this autonomy has also created space for local order and the establishment of place-based institutions and norms that act to augment (and sometimes conflict with) formal rules and regulations. On the individual-level, for example, some illegal clam harvesting is ignored, especially in instances where the violators are viewed as being in need and having no other way to earn money to support themselves or their families. There is also community-level rule making that transpires. For example, local residents work to occupy shellfish "territories" out on the expansive mudflats in an effort to keep other people from nearby communities from benefitting from the softshell fishery. These mudflat wars are visible in the shellfish committee meetings, where rules have recently been implemented to restrict the number of harvesters and increase the price of licenses, but much of the conflict transpires in informal venues. Similar turfs are also famously created and defended by those who fish for lobster (Acheson, 2003) and by scallop fishers in the region who are currently trying to keep outsiders from mooring near local fishing hotspots by passing town ordinances that prevent the use of temporary mooring anchors. Locally negotiated rules also emerge from interactions with members of the Passamaquoddy 
tribe and from fishing in close proximity to Canadian fishers. In the case of Canada, the rule making process stems from the contested international boundary and inconsistent fishing regulations that are viewed as disadvantageous to US-based fishers. This contested area, unofficially known as the Grey Zone, includes prime fishing grounds that fishermen from the US and Canada both occupy. Where Maine-based fishers fish adjacent to boats from the nearby Canadian Maritime Provinces, fishers have had to essentially create their own code of conduct.

The independence that is afforded by the region's isolation means that members of the fishing community Downeast play a critical role in shaping the everyday order in the region even though most do not occupy formal positions of authority or power. To a certain extent, this makes the region similar to other places where authority has been devolved to fishers (intentionally or by virtue of weak enforcement and lack of oversight) (e.g., Campbell et al., 2013; Christie et al., 2007; Karlsen, 2001; Nasuchon and Charles, 2010). Thus, while the research presented in this paper is specific to the region, the insights that are derived from it about the interplay between social-ecological linkages and leadership are likely more broadly relevant.

2.2. Using social network data to identify leaders

Leaders were identified as part of a broader interdisciplinary research initiative to assess community assets in eastern Maine. The social and ecological distinctness of the region was used to constrain the geographic scope of the asset mapping project and, in turn, the research presented in this paper. The data used to identify these actors were collected through a survey of 
commercial fishers in Washington County that was administered during the spring and summer of 2015 by way of a phone and in-person survey. Data were not collected in Hancock County or the islands in Penobscot Bay that are not accessible by road due to time and resource constraints. Survey participants were asked a series of questions to solicit information about whom they go to with ideas about improving their fisheries or to solicit help if they encounter a problem related to natural resource management or governance. Fishers were purposefully directed to identify the actors that they go to for "improvement" and "problem solving" related to fisheries management and governance rather than simply general help with day-to-day issues (e.g., boat maintenance or gear repair) in an effort to focus in on leaders that act as IEs. Three types of network data were collected for each actor identified by respondents: (1) relationship (friend, kin, professional), (2) geographic proximity (town, county, state), and (3) frequency of communication (weekly, monthly, yearly). Notes were also recorded to capture additional commentary that fishers offered during the surveys. This information included detailed character profiles of other actors in the area as well as more general perspectives on the state of fisheries and fisheries management. While data on relationship, geography and frequency were not used in this paper, the supplementary information was use to contextualize the research and interpret the results. The length of the interviews ranged from approximately ten minutes (essentially the time it took to answer the questions without offering broader input) to upwards of ninety minutes if a respondent wanted to share his or her views on fisheries in the region.

The survey data were used to construct a unidirectional social network describing the different actors that fishers in the region go to with ideas about improving their fisheries or for help solving fisheries management and governance problems. Network centrality was then measured 
to locate the most influential actors in the network (Wasserman and Faust, 1994). In this paper, I focus on actors that were identified by at least 5 fishers, because these individuals likely have the greatest domain of influence and therefore are most capable of facilitating transformative change. This is consistent with the literature on IEs, which emphasizes the critical role that network centrality plays in helping IEs bring about change (Powell and DiMaggio, 2012). The threshold also provides a conservative measure to limit Type II error (or the false identification of leaders). In particular, this approach provides a mechanism to exclude actors who were identified as being important figures by survey participants because, for example, they worked on their boats or because they are close friends or family members, but who are not more broadly recognized as leaders in the region. For this analysis, I used degree centrality instead of betweenness centrality because it is a more reliable indicator of influence when using partial network data because degree centrality tends to be correlated with full networks (Costenbader and Valente, 2003). Nonetheless, it is important to acknowledge that the network data used to identify these leaders do not represent the entire social network of commercial fishers in the region or Maine. Therefore, the analysis provides a systematic but not definitive approach to identifying the key actors in the region.

2.3. Using licensing data to understand fishers' level of diversification

To quantify fishers' level of diversification, fishing portfolios were calculated for all fishers in Washington County (and Maine in general) as described in Stoll et al. (in review). In short, each portfolio describes the assemblage of fisheries that an individual has access to based on the state 
and federal licenses that she or he holds. The mean size of fishing portfolios for the entire state and Washington County were then compared to the mean fishing portfolios for leaders using a Wilcoxon rank-sum test to test the hypothesis that the mean number of fisheries accessed by nonleaders and leaders is the same. ${ }^{2}$

2.4. Using interview data to interpret significance of fisher portfolios

In-depth interviews were subsequently conducted with a subset of the leaders identified in the social network analysis ( 8 of 17 ) as a way to add depth to the interpretation of the results. These semi-structured interviews provided an opportunity to learn more about the leaders, their role(s) in the region, and how they have (and continue to) interact with the marine environment. All of the interviews were conducted in Washington County at a location of the interviewees own choosing - often at home or in a place of business. Interviews lasted between forty-five minutes and approximately two hours. These interviews were transcribed and then subsequently coded in NVivo 11.0 using a modified grounded theory approach to identify themes (Corbin and Strauss, 2008).

3. Results and discussion

3.1. Are leaders more diversified than other fishers? 
Survey data were collected from 382 fishers who collectively hold $35 \%$ of the commercial fishing licenses in Washington County. These individuals held 1 to 13 licenses. Few fishers ( $\mathrm{n}=$ 19) were unwilling to participate in the survey. Survey respondents included representatives from across the county who participate in the spectrum of commercial fisheries in the state from the lucrative elver fishery to the iconic lobster fishery. Coverage of individual fisheries ranged from as high as $73 \%$ in the scallop fishery to as low as $20 \%$ in the marine worm fishery.

Survey participants identified 225 individuals in response to the initial survey (Fig. 2). The mean number of actors identified per survey participant was 1.8. These actors can be subdivided into four general categories: (1) individuals directly engaged in the fishing industry, (2) government officials, (3) family members not in fisheries, and (4) researchers and non-profit representatives. Types $1(\mathrm{n}=157)$ and $2(\mathrm{n}=32)$ were the most common class of people identified, as expected, because the survey specifically sought to solicit names of people who solve problems or forward ideas in fisheries and not more broadly. In this paper, I focus on the subset of identified actors who are directly engaged in commercial fishing (Type 1). Government officials (Type 2) were not included because while their role in shaping policy and management is critical, these individuals' leadership is a feature of their formal positions and is therefore fundamentally different than that which exists in the fishing industry itself.

Of the 225 actors that fishers identified, 27 were identified by at least 5 different fishers (Fig. 2). Within this subset 17 individuals are commercial fishers. The remainder included law enforcement agents and fisheries managers $(n=8)$ and representatives from non-governmental 
organizations and academic institutions $(n=2)$. Of the 17 commercial fishers, 8 were interviewed.

The 8 individuals that were interviewed as part of this research generally resemble the broader fishing sector in terms of age, race, and education. Interviewees ranged in age from 50 to 66 years old. This is similar to the average age of commercial fishers in Maine, which is 50 years old (C. Fetterman, personal communications). All interviewees were Caucasian and one was female. Although there are no data on race or gender for fishers in Maine, personal observation suggests that the sector is predominantly white and male. This is further supported by census data that shows that $91.5 \%$ of Washington County residents are Caucasian (U.S. Census Bureau, 2012). Those who were interviewed all have a high school diploma and three had some level of vocational training or undergraduate education. This is similar to the county average for high school graduation (87.7\%) and higher education (20.1\%) (U.S. Census Bureau, 2012). On average, interviewees had more than three decades of commercial fishing experience, ranging from 16 to 53 years. All had or currently serve on fisheries advisory committees at the town or state level.

The results of the Wilcoxon rank-sum test show that leaders are significantly more diversified in terms of their fishing portfolios than the broader population in Washington County $(\mathrm{W}=22,672$, $\mathrm{P}=3.094 \times 10^{-5}$, Wilcoxon rank-sum test, continuity correction applied) and Maine (W $=115,208.5, P=6.744 \times 10^{-7}$, Wilcoxon rank-sum test, continuity correction applied). This result does not change based on survey participants' own level of diversification; there is no 
significant difference between the fishing portfolios of leaders identified by fishers that only hold 1 license versus those who are more diversified $(\mathrm{W}=4378.5, \mathrm{P}=0.1794)$. The mean number of commercial fishing licenses held by fishers in Maine is 1.75 licenses (median $=1$, standard deviation $=1.63$ ) with a high of 16 . The mean number of commercial fishing licenses held by residents of Washington County is slightly higher $($ mean $=1.89$, median $=1$, standard deviation $=1.59$ ) with a high of 15 . The mean number of commercial fishing licenses held by leaders is nearly two times higher than the county or state means (mean $=3.53$, median $=3$, standard deviation $=2.18$ ).

3.2. How do diverse social-ecological linkages facilitate leadership?

There is growing recognition that leadership is facilitated by the connections (i.e., relationships) that actors maintain rather than their personal traits alone. To this point, Evans et al. (2015) describe leadership as "relational as opposed to individualistic." This is not to dismiss the importance of individuals or their attributes entirely, but rather to acknowledge that they fit within a broader context that is of equal (if not greater) importance. This perspective is supported by an increasing number of empirical case studies from around the world that demonstrate that leaders' capacity is closely associated with their position in social networks and the social capital they maintain (Alexander et al., 2015; Crona and Bodin, 2010; Stoll et al., 2015). The relationships of interest in this paper are not strictly the social ties, but also those between actors and the environment. This interest stems from the finding that leaders are more diversified than other fishers in the region. To fully acknowledge these linkages requires extending the notion of 
leadership as "relational" to include the ecological domain, since actors can also derive benefits or "capital" from the natural environment. Here, I use data from interviews with leaders to explore three possible ways leaders' diverse ties to fisheries may help them improve the socialecological conditions of their communities. These findings are situated within the existing theory on institutional entrepreneurship.

\subsubsection{Imagining alternatives}

Despite the relative autonomy that fishers in eastern Maine have, many industry members do not feel they have the capacity to effect change. Indeed, even though 225 different actors were identified as potential leaders through the survey, including 17 industry members who were identified by 5 or more fishers, 117 fishers indicated that they did not have anyone to go to with ideas about improving their fisheries. This perception, at least in part, seems to be based on a set of often-cited management decisions that actors view as antagonistic and inequitable. These include rules to protect endangered North Atlantic Right whales that have been costly to those engaged in the lobster fishery; size restrictions on halibut and lobster that preferentially favor Canadian fishers; and rotating scallop areas that let fishers "from away" access local fishing spots. These kinds of management decisions are a central part of actors' collective memory and cumulatively support feelings of helplessness and loss, which in turn fuel a sense of mistrust and justify apathy. 
Leaders in the region are intimately familiar with the events of the past and often share the same frustrations of other fishers, but they appear to be less immobilized by the outcomes that have transpired. This difference may be partly explained by the diverse connections that these leaders have to fisheries and how these connections facilitate learning and enable imaginative thinking about alternative opportunities. This premise is based on the theoretical foundation used by Granovetter (1973) and others to argue that weak links and bridging capital are pivotal to acquiring new knowledge in social systems and developing alternative visions. Specifically, just as weak links have been shown to provide a pathway through which new information is gained and local innovation is spurred, diversification can serve the same function by allowing actors to learn about different gears, markets, and regulations and in doing so apply knowledge gained in one fishery to others.

The relationship between being able to imagine alternatives and fishers' access to different fisheries is particularly evident in the ways that leaders speak about marine resources as sources of untapped economic potential. As one leader explained, "I think the average fisherman doesn't understand really that there is literally a market for everything that's out in the bay in some way, shape, or form." Later the leader added:

Just look at seaweed. Ten years ago, no one even really knew what seaweed was unless you went in the Asian foods section of a decent supermarket. Now, ten years later, people are like, oh, dulse, oh, sea lettuce. People actually know the names. It's not just green slime anymore. It's seaweed. You know, if you go ten 
years from now, there may be a dulse farm and a sea lettuce farm, and a kelp

farm, and - no one quite understands. I mean, I could probably sell 30,000

lumpfish a year for $\$ 300.00$ bucks a piece if I had the manpower.

Leaders that are able to imagine alternative market opportunities like this stand to benefit on a personal level. Yet the infusion of new ideas into a region like Downeast also proves beneficial at a broader, community level by demonstrating that there are opportunities for fishers to continue to make a living on the water, even if many of the ways that they have participated in fisheries in the past no longer exist (either because certain fisheries have declined or regulations have limited entry).

\subsubsection{Devising and framing solutions}

An important part of leadership is being able to devise and frame solutions in ways that resonate with and are coherent to other actors in a social network (Battilana et al., 2009). This requires knowledge of the system within which leaders are operating. In the case of fisheries, knowledge comes from interacting with other fishers and with the natural environment. Fishers interact with marine systems in ways that few others do, including researchers, policymakers, and managers. These interactions are dictated by the specifics of the fisheries that fishers participate in (e.g., gear type, geography, and season) and influence the kind of information that they can glean from the system (which ultimately shapes their local ecological knowledge). For example, a clam digger that harvests softshell clams from Maine's expansive mud flats is going to know a lot 
about the intricacies of tides, sediment, and the effects of runoff on coastal water quality whereas a lobster fisher will be much more fluent in the complexities of, for example, water temperature, currents, molting patterns, and rock crab populations.

Actors that are involved in more than one fishery invariably engage with different components of the environment. Having multiple vantage points is thought to facilitate broader learning about the system (Stoll et al., 2016). This ability to observe how different parts of the system interact gives diversified actors a more comprehensive view of the marine system than fishers who are more specialized. The sensitivity to these social-ecological dynamics is evident in the way that the leaders in Downeast Maine described the fisheries that they exploit. The following description of the ecological coupling of the worm and clam fisheries provides an illustrative example:

You may find clams and worms on the same flat, but one is going to be more than the other. And then the next year it might be the other way. Or two years down the road it may be the other way. And then two years down the road it switches back ... they work interchangeably.

This kind of social-ecological knowledge is a result of direct participation in both fisheries. In this specific instance, it came from being bent over the mudflats for decades, learning how to forge a living from two separate, but intertwined species - softshell clams and worms. Without interacting with both fisheries in this way, such relationships are essentially invisible. 
Leaders in Downeast Maine are particularly well positioned to use their knowledge about local social-ecological dynamics to both devise and frame strategies to minimize negative impacts of fishing and devise ways to improve the systems. ${ }^{3}$ This process of using social-ecological knowledge - derived from experience gained from participating in multiple fisheries - to develop strategies for the benefit of fisheries (and therefore the broader community) seems to be common among the leaders that were interviewed. For example, the same leader that described the ecological connections between worms and softshell clams has also been working on maintaining the productivity of the mud flats by way of "reseeding" worms that were injured or bisected in the harvesting process.

There are certain worms whether they are too small or they're cut or they're dead that we can't sell. So we put them back. We take them down to the shore and put them back, so we call it a reseeding program. Worms are very interesting. They when they are put back in the mud, they can re-heal themselves. If they are cut to the point where they have lost their tail, they will grow a new tail ... Sometimes they have what they call a - they pull the head out so the worm can't retract its head. And sometimes that can also be re-healed. Heard stories that they can grow new heads from if you put the tail back, they will grow a new head. Never seen one. Fairy tale, myth. I have seen the new back ends, so I do know that they can re-grow their back ends ... But if the small worms are seeded back into the mud, they - that gives them a chance to grow and so that you can dig them at a later time and have a sellable worm. 
This program, which appears to be supported by worm diggers in the area, is being operated under the radar of formal management efforts, for the purpose of trying to sustain local worm digging areas. It was created based on a leader's understanding of the ecology of worms and how they function within the broader intertidal system and appears to be a reason that other fishers see the actor as a leader. This is important, not only to maintain worm harvesting, but also in sustaining the mudflats more generally:

If you go to a flat and you can dig worms, there are usually very few clams. After the worms are harvested diggers move to another - other flats, the mud is ruffled so that when the seed from the clams wash on shore, the mud catches it. And the clams come in and will grow. So the clam diggers can come and harvest. And then the worms come back. So it's an ongoing process to keep one or the other viable $\ldots$

\subsubsection{Engaging in change}

A third way diversification appears to facilitate leadership is by fostering stability for actors, thus enabling them to participate in the management process bring about change. Fish stocks often respond to social and ecological disturbances in unpredictable ways, causing chronic uncertainty for fishers. Having access to a diverse portfolio of unrelated fisheries can reduce the risk of 
uncertainty. This, in turn, would dampen the economic effects of fluctuations in any individual fishery (Kasperski and Holland, 2013). This is part of the reason there is mounting concern in the lobster fishery in Maine even though landings are at a near-record high (Steneck et al., 2011). With 2832 fishers in Maine solely dependent on lobster (Stoll et al. in review), a sudden decline would almost certainly cause an immediate socioeconomic disaster for many industry members.

The benefits of being diversified were explicitly acknowledged by several of the leaders interviewed for this research. To this point, one leader observed:

Well when scalloping started to go into the tank, sea urchins were rising up. So you could get a lot more money, a lot less effort, a lot less fuel - and if fuel is $\$ 4.00$ a gallon you don't want to burn a lot of fuel to catch your product. Sea urchins went up. Scallops hit the bottom. Most everybody that had a scallop license had a sea urchin license - most of them, not all - but most did. So they switched from targeting scallops to targeting sea urchins. That gave the scallops a reprieve so they could basically come back on their own. Mother Nature is doing her thing. And now it's right the opposite. You know sea urchins are starting to get in the tank because - I mean the price is good but there aren't as many around.

This ability to shift between species during different seasons or when a species declines or is closed by regulations gives fishers economic stability that translates into livelihood security. Such security is arguably not the norm given that nearly 6000 fishers in Maine only have access 
to one license (and with the exception of the federal lobster permit it is difficult to make a living fishing year around with access to only one fishery). This is not to suggest that all of these fishers are trying to operate in fisheries, full-time, but for those individuals that are, being diversified has a distinct advantage. Specifically, it means that fishers do not need to invest as much time or energy searching for alternative employment opportunities during the offseason. In the words of one interviewee, "[Being diversified is] the only way that I can have full-time employment in the winter ... And employment in the winter around here is pretty sacred." This stability creates the latitude for leaders to pursue other endeavors, including, importantly, participating in the management process. Such participation seems to be nearly ubiquitous among the leaders who were interviewed (only one indicated that he no longer participates in fisheries management meetings on account of his age). One interviewee explained:

I've never missed a meeting. I was to every meeting that we were supposed to have had whether it was in Augusta or Ellsworth, Machias or Bangor or wherever it was. I would take off from work and I would go. I would take off a day of dragging to go.

Having access to multiple fisheries and year-round employment also allows individuals to accrue savings, which in turn, make fishers less dependent on maximizing fishing opportunities. One leader explained his situation as follows: "Scallop fishing is something that gets us through the winter. I mean it ain't our livelihood. It's lobstering ... You can make enough while it's going on in three days a week, but you don't have to dig into your lobster money. Yes, I'm very fortunate 
because I've got the other two licenses, you know?" In contrast, those dependent on a single fishery do not have the same leeway and therefore need to maximize fishing opportunities, often at the expense of participating in the management process. As another interviewee observed:

We have some of the smartest frigging people, going as far as fishing goes or rigging of drag or running a boat in the fog or towing a piece of bottom and understanding our astronomical tides. Those people have to go to work every day. They know what the problems are. So they call a meeting in Augusta. And they they're - they're not gonna take a day off from fishing and drive down to Augusta ... [So] I get in the truck and drive to Augusta by myself sometimes. I'm so fucking mad. And testify. Or spend the night down there and testify.

This pattern of participation, in turn, leads these actors to take on the de facto role of spokesperson for their communities.

\section{Conclusion}

This research provides evidence that leaders in a rural region of Maine have more diverse ties to marine resources than other fishers. Drawing on interviews with a subset of these leaders, I put forward three hypotheses to explain the correlation between leadership and diversification. While further research is needed to build theory around this interplay, these findings support the view 
that scholarship on leadership needs to be explicit about both the social and the ecological processes that shape leadership; in other words, to broaden the focus beyond individuals and their personal and social attributes.

The apparent role that diversification plays in facilitating leadership in fishing communities raises important governance questions, particularly within the context of increasing use of neoliberal fisheries management tools worldwide that are driving privatization and specialization (Carothers, 2015). In particular, the central question that emerges from this research is: to what extent could the trend towards specialization in fisheries alter the production of leadership in coastal communities and the roles these leaders play in supporting sustainable social-ecological systems? It seems unlikely that as fishers' portfolios become narrower (due to regulations that limit access) leaders will simply cease to exist, but it is not unreasonable to hypothesize that future leaders will have more limited relationships to the ecosystem due to their more specialized expertise. This scenario could be detrimental to the overall well-being of coastal communities because leaders with a more limited view are likely to be constrained in their ability to understand the marine system holistically and therefore could be prone to advocating for overly narrow solutions that do not serve their communities broadly.

To avoid this situation, creative policy solutions that increase fishers' access to fisheries without causing overfishing are critical. This represents a significant challenge with no clear-cut solution, particularly because in most places fisheries are already being exploited at or above rates that are considered sustainable. Here, I do not attempt to offer a definitive solution to address this 
challenge, but rather put forward a recommendation. Over the course of this research, I had the opportunity to learn about and speak with a number of leaders who are finding ways to sustain their livelihoods and contribute to the broader sustainability of their communities and the ecosystems that they depend on. Each of these individuals has an immense amount of placebased knowledge that clearly shapes their insights about the challenges and opportunities that exist (some of which are captured in the quotes provided above). It is quite possible that the most viable strategies for increasing fishers' fishing portfolios without undermining the ecology of the system could come from these leaders. This idea, which draws on existing paradigms of local and co-management (Armitage et al., 2009; Ostrom, 2015; Pinkerton, 1989), is based on the view that fisheries are inherently complex and dynamic coupled social-ecological systems and those with intimate knowledge of the local processes and interconnections are critical to the development of durable, multi-scale policies and institutions. To take advantage of this knowledge, managers and policymakers must engage with and listen to these leaders.

Acknowledgements

This work was supported by the National Fish and Wildlife Foundation [\# 41474 (2014)] as part of a broader asset mapping project in eastern Maine and by the Michael J. Eckardt Fellowship Program and Mitchell Center for Sustainability Solutions at the University of Maine, Orono. I extend my appreciation to the members of the commercial fishing industry who took part in the initial survey to support this research and those who were identified as leaders, all of whom so graciously shared their knowledge and perspectives. I further express my thanks to James 
Wilson, Beatrice Crona, and two anonymous viewers for their constructive feedback, which greatly improved the quality of this manuscript. 
References

Acheson, J., 2003. Capturing the Commons: Devising Institutions to Manage the Maine Lobster Industry. University Press of New England, Lebonon, NH.

Alexander, S., Armitage, D., Charles, A., 2015. Social networks and transitions to comanagement in Jamaican marine reserves and small-scale fisheries. Glob. Environ.

Change 35, 213e225. http://dx.doi.org/10.1016/j.gloenvcha.2015.09.001.

Armitage, D., Plummer, R., Berkes, F., Arthur, R., Charles, A., Davidson-Hunt, I., Diduck, A., Doubleday, N., Johnson, D., Marschke, M., McConney, P., 2009. Adaptive comanagement for socialeecological complexity. Front. Ecol. Environ. 7 (2), 95e102.

Battilana, J., Leca, B., Boxenbaum, E., 2009. How actors change institutions: towards a theory of institutional entrepreneurship. Acad. Manag. Ann. 3, 65e107. http:// dx.doi.org/10.1080/19416520903053598.

Biggs, R., Westley, F., Carpenter, S., 2010. Navigating the back loop: fostering social innovation and transformation in ecosystem management. Ecol. Soc. 15, 1e25.

Bodin, O., Crona, B., Thyresson, M., Golz, A.-L., Tengo, M., 2014. Conservation success as a function of good alignment of social and ecological structures and processes. Conserv. Biol. 28, 1371e1379. http://dx.doi.org/10.1111/cobi.12306.

Bodin, O., Crona, B.I., 2008. Management of natural resources at the community level: exploring the role of social capital and leadership in a rural fishing community. World Dev. 36, 2763e2779. http://dx.doi.org/10.1016/ j.worlddev.2007.12.002. 
Bodin, O., Tengo, M., 2012. Disentangling intangible socialeecological systems. Glob. Environ. Change 22, 430e439. http://dx.doi.org/10.1016/j.gloenvcha.2012.01.005.

Brzeinski, D., Wilson, J., Chen, Y., 2010. Voluntary participation in regional fisheries management council meetings. Ecol. Soc. 15, 1e14.

Bundy, A., Davis, A., 2013. Knowing in context: an exploration of the interface of marine harvesters' local ecological knowledge with ecosystem approaches to management. Mar. Policy 38, 277e286.

Campbell, S.J., Kartawijaya, T., Yulianto, I., Prasetia, R., Clifton, J., 2013. Co-management approaches and incentives improve management effectiveness in the Karimunjawa National Park, Indonesia. Mar. Policy 41, $72 \mathrm{e} 79$. http://dx.doi.org/10.1016/j.marpol.2012.12.022.

Carothers, C., 2015. Fisheries privatization, social transitions, and well-being in Kodiak, Alaska. Mar. Policy 1e10. http://dx.doi.org/10.1016/j.marpol.2014.11.019.

Christie, P., Fluharty, D., White, A., Eisma-Osorio, L., Jatulan, W., 2007. Assessing the feasibility of ecosystem-based fisheries management in tropical contexts. Mar. Policy 31, 239e250. http://dx.doi.org/10.1016/j.marpol.2006.08.001.

Corbin, J., Strauss, A., 2008. Basics of Qualitative Research, third ed. Sage, Thounsand Oaks, California.

Costenbader, E., Valente, T., 2003. The stability of centrality measures when networks are sampled. Soc. Netw. 25, 283e307. http://dx.doi.org/10.1016/S0378-8733(03)00012-1. 
Crona, B., Bodin, O., 2010. Power asymmetries in small-scale fisheries: a barrier to governance transformability? Ecol. Soc. 15, 1e18.

Crona, B., Bodin, O., 2006. What you know is who you Know? Communication patterns among resource users as a prerequisite for Co-management. Ecol. Soc. 11.

Davis, A., Wagner, J., 2003. Who Knows? On the importance of identifying “experts" when researching local ecological knowledge. Hum. Ecol. 31, 463e489.

Emirbayer, M., Mische, A., 1998. What is agency? Am. J. Sociol. 103, 962e1023. http://dx.doi.org/10.1086/231294.

Evans, L., Hicks, C., Cohen, P., Case, P., Prideaux, M., Mills, D.J., 2015. Understanding leadership in the environmental sciences. Ecol. Soc. 20, art50eart118. http:// dx.doi.org/10.5751/ES-07268-200150.

García-Quijano, Carlos G., 2009. Managing complexity: ecological knowledge and success in puerto rican small-scale fisheries. Hum. Organ. 68, 1 e17.

Garud, R., Hardy, C., Maguire, S., 2007. Institutional entrepreneurship as embedded agency: an introduction to the special issue. Organ. Stud. 28, 957e969. http://dx.doi.org/10.1177/0170840607078958.

Gilmour, P.W., Dwyer, P.D., Day, R.W., 2013. Enhancing the agency of fishers A conceptual model of self-management in Australian abalone fisheries. Mar. Policy 37, 165e175. http://dx.doi.org/10.1016/j.marpol.2012.04.015. 
Goodman, K., Goodman, Y., 1978. Reading of American Children Whose Language Is a Stable Rural Dialect of English or a Language Other than English (No. NIE-C-00-3-0087). National Institute of Education, Washington, DC.

Granovetter, M.S., 1973. The strengthen of weak ties. Am. J. Sociol. 78, 1360e1380.

Greenwood, R., Suddaby, R., Hinings, C.R., 2002. Theorizing change: the role of professional associations in the transformation of institutionalized fields. Acad. Manag. J. 45, 58e80.

Gutiérrez, N., Hilborn, R., Defeo, O., 2011. Leadership, social capital and incentives promote successful fisheries. Nature 470, 386e389. http://dx.doi.org/10.1038/ nature09689.

Hannan, M., Freeman, J., 1984. Structural intertia and change. Am. Sociol. Rev. 49, $149 \mathrm{e} 164$.

Hirsch Hadorn, G., Bradley, D., Pohl, C., Rist, S., Wiesmann, U., 2006. Implications of transdisciplinarity for sustainability research. Ecol. Econ. 60, 119e128. http:// dx.doi.org/10.1016/j.ecolecon.2005.12.002.

Karlsen, G., 2001. Can formalisation help? The introduction of fisheries co-management in the inshore fisheries of Dingle, Co. Kerry, Ireland. Mar. Policy 83e89.

Kasperski, S., Holland, D., 2013. Income diversification and risk for fishermen. Proc. Natl. Acad. Sci. 110, 2076e2081. http://dx.doi.org/10.1073/pnas.1212278110/-/ DCSupplemental.

Khan, F., Munir, K., Willmott, H., 2007. A dark side of institutional entrepreneurship: soccer balls, child labour and postcolonial impoverishment. Organ. Stud. 28, $1055 \mathrm{e} 1077$. http://dx.doi.org/10.1177/0170840607078114. 
Lawrence, T.B., 2004. From moby dick to free willy: macro-cultural discourse and institutional entrepreneurship in emerging institutional fields. Organization 11, 689e711. http://dx.doi.org/10.1177/1350508404046457.

Levy, D., Scully, M., 2007. The institutional entrepreneur as modern prince: the strategic face of power in contested fields. Organ. Stud. 28, 971e991. http://dx.doi.org/10.1177/0170840607078109.

Lounsbury, M., Crumley, E., 2007. New practice creation: an institutional perspective on innovation. Organ. Stud. 28, 993e1012. http://dx.doi.org/10.1177/0170840607078111.

Maguire, S., Hardy, C., Lawrence, T., 2004. Institutional entrepreneurship in emerging fields: HIV/AIDS treatment advocacy in Canada. Acad. Manag. J. 47, 657e679.

McCarthy, D., Whitelaw, G., Westley, F., Crandall, D., Burnett, D., 2014. The oak ridges moraine as a social innovation: strategic vision as a social-ecological interaction. Ecol. Soc. 19, art48eart112. http://dx.doi.org/10.5751/ES-06212-190148.

McLaughlin, P., Dietz, T., 2008. Structure, agency and environment: toward an integrated perspective on vulnerability. Glob. Environ. Change 18, 99e111. http://dx.doi.org/10.1016/j.gloenvcha.2007.05.003.

McPherson, M., Smith-Lovin, L., Cook, J., 2001. Birds of a feather: homophily in social networks. Annu. Rev. Sociol. 27, 415e444.

Nasuchon, N., Charles, A., 2010. Community involvement in fisheries management Experiences in the Gulf of Thailand countries. Mar. Policy 34, 163e169. http://dx.doi.org/10.1016/j.marpol.2009.06.005. 
NOAA, 2016. Mapping Social Vulnerability. http://www.st.nmfs.noaa.gov/

humandimensions/social-indicators/map (Accessed 27 February 2017).

Olsson, P., Folke, C., Hahn, T., 2013. Social-ecological transformation for ecosystem management: the development of adaptive co-management of a wetland landscape in southern Sweden. Ecol. Soc. 9, 1e19.

Olsson, P., Folke, C., Hahn, T., 2004. Social-ecological transformation for ecosystem management: the development of adaptive co-management of a wetland landscape in southern Sweden. Ecol. Soc. 9, 4.

Olsson, P., Gunderson, L., Carpenter, S., Ryan, P., Lebel, L., Folke, C., Holling, C.S., 2006. Shooting the rapids: navigating transitions to adaptive governance of social-ecological systems. Ecol. Soc. 11, 18.

Ostrom, E., 2015. Governing the Commons. Cambridge University Press.

Perkmann, M., Spicer, A., 2007. 'Healing the scars of history': projects, skills and field strategies in institutional entrepreneurship. Organ. Stud. 28, 1101e1122. http://dx.doi.org/10.1177/0170840607078116.

Pinkerton, E., 1989. Co-operative Management of Local Fisheries: New Directions for Improved Management and Community Development. University of British Columbia Press, Vancouver.

Powell, W., DiMaggio, P., 2012. The New Institutionalism in Organizational Analysis. University of Chicago Press. 
Pretty, J., 2003. Social capital and the collective management of resources. Science 302, $1912 \mathrm{e} 1914$.

Rosen, F., Olsson, P., 2013. Institutional entrepreneurs, global networks, and the emergence of international institutions for ecosystem-based management the Coral Triangle Initiative. Mar. Policy 38, 195e204. http://dx.doi.org/10.1016/ j.marpol.2012.05.036.

Schusler, T., Decker, D., Pfeffer, M., 2003. Social learning for collaborative natural resource management. Soc. Nat. Resour. 16, 309e326. http://dx.doi.org/10.1080/08941920390178874.

Seo, M., Creed, W., 2002. Contraditions, praxis, and institutional change: a dialectical perspective. Acad. Manag. Rev. 27, 222e247.

Steenbergen, D.J., 2016. Strategic customary village leadership in the context of marine conservation and development in southeast maluku, Indonesia. Hum. Ecol. 1e17. http://dx.doi.org/10.1007/s10745-016-9829-6.

Steneck, R., Hughes, T., Cinner, J., Adger, W., Arnold, S., Berkes, F., Boudreau, S., Brown, K., Folke, C., Gungerson, L., Olsson, P., Scheffer, M., Stephenson, E., Walker, B., Wilson, J., Worm, B., 2011. Creation of a gilded trap by the high economic value of the Maine lobster fishery. Conserv. Biol. 25, 904e912. http://dx.doi.org/10.1111/j.1523-1739.2011.01717.x.

Stoll, J., Beitl, C., Wilson, J., 2016. How access to Maine's fisheries has changed over a quarter century: the cumulative effects of licensing on resilience. Glob. Environ. Change 37, 79e91. http://dx.doi.org/10.1016/j.gloenvcha.2016.01.005. 
Stoll, J., Dubik, B., Campbell, L., 2015. Local seafood: rethinking the direct marketing paradigm. Ecol. Soc. 20, 1e14. http://dx.doi.org/10.5751/ES-07686-200240.

Sutton, A., Rudd, M., 2016. Factors influencing community fishers' leadership engagement in international small-scale fisheries. Front. Mar. Sci. 3, 1036e1117. http://dx.doi.org/10.3389/fmars.2016.00116.

Sutton, A.M., Rudd, M.A., 2014. Deciphering contextual influences on local leadership in community-based fisheries management. Mar. Policy 50, 261e269. http://dx.doi.org/10.1016/j.marpol.2014.07.014.

U.S. Census Bureau, 2012. QuickFacts: Washington County, Maine. http://www. census.gov/quickfacts/table/WTN220212/23029 (Accessed 26 February 2017).

Wasserman, S., Faust, K., 1994. Social Network Analysis: Methods and Applications. Cambridge University Press, Cambridge.

Welter, F., Smallbone, D., 2011. Institutional Perspectives on Entrepreneurial Behavior in Challenging Environments, vol. 49, pp. 107e125.

Westley, F., Olsson, P., Folke, C., Homer-Dixon, T., Vredenburg, H., Loorbach, D., Thompson, J., Nilsson, M., Lambin, E., Sendzimir, J., Banerjee, B., Galaz, V., van der Leeuw, S., 2011. Tipping toward sustainability: emerging pathways of transformation. AMBIO 40, 762e780. http://dx.doi.org/10.1007/s13280-011-0186-9.

Westley, F.R., Tjornbo, O., Schultz, L., Olsson, P., Folke, C., Crona, B., Bodin, O., 2013. A theory of transformative agency in linked social-ecological systems. Ecol. Soc. 18, art27eart116. http://dx.doi.org/10.5751/ES-05072-180327. 
Zilber, T.B., 2007. Stories and the discursive dynamics of institutional entrepreneurship: the case of israeli high-tech after the bubble. Organ. Stud. 28, 1035e1054. http://dx.doi.org/10.1177/0170840607078113. 


\section{Footnotes}

${ }^{1}$ Most federal fisheries meetings are held more than 350 miles from the region process (Brzeinski et al., 2010).

${ }^{2}$ Reducing the threshold for leadership (i.e., below 5) did not significantly change the results of the analysis.

${ }^{3}$ Much has been written about the role that local ecological knowledge plays in fisheries (e.g., Bundy and Davis, 2013; Davis and Wagner, 2003; García-Quijano, 2009). 


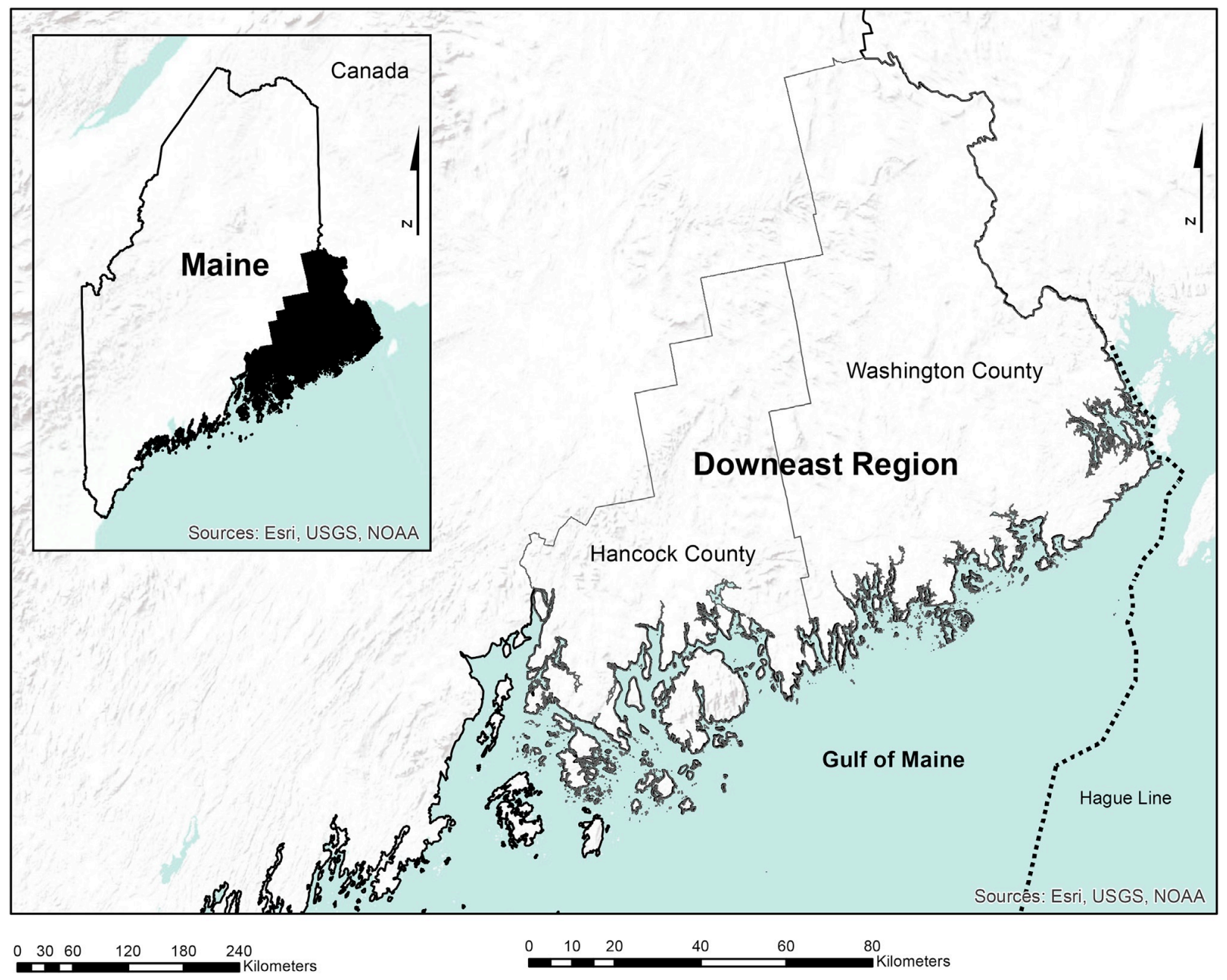

Fig. 1. Study area. Map of Downeast region of Maine, United States. 

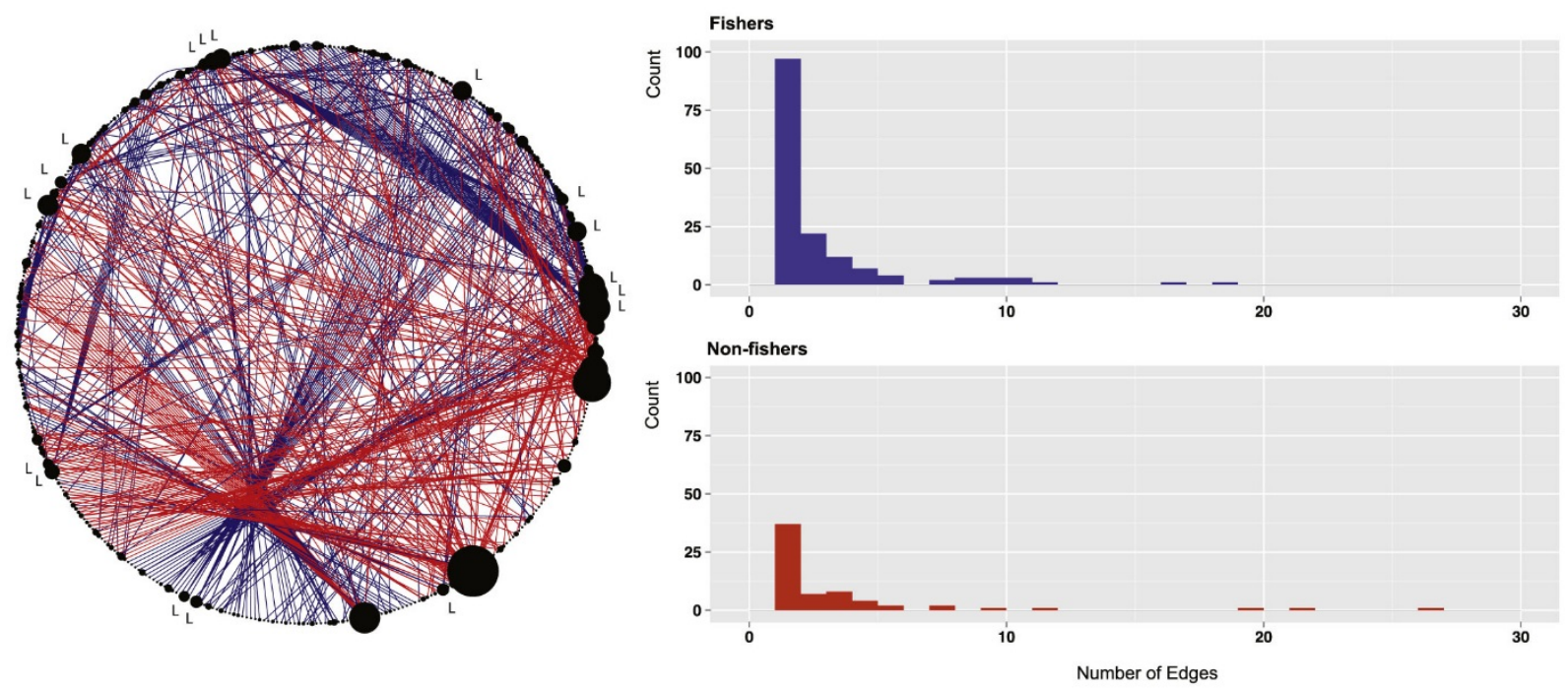

Fig. 2. Leaders in Eastern Maine. (Left) The network of commercial fishers in Washington County based on the actors that fishers go to with ideas about improving their fisheries or to solicit help if they encounter a problem related to natural resource management or governance. Blue edges represent connections between fishers. Red edges represent fishers' connections to non-fishers. The size of the black node depicts relative centrality of each actor. L denotes fishing industry leaders identified by at least 5 fishers. (Right) Number of fishers (top) and non-fishers (bottom) identified by survey participants as potential leaders. 